\title{
分散コンポーネント型ロボットシミュレータ OpenHRP3
}

OpenHRP3: A Robot Simulator Implemented as Distributed Objects

中 岡 慎一郎*1 山野辺 夏 樹*1 比留川 博 久*1 山 根 克*2 川 角 祐一郎*3 *1 産業技術総合研究所 $* 2$ 東京大学 $* 3$ ゼネラルロボティックス株式会社 Shin'ichiro Nakaoka*1, Natsuki Yamanobe*1, Hirohisa Hirukawa*1, Katsu Yamane ${ }^{* 2}$ and Yuichiro Kawasumi*3 ${ }^{* 1}$ AIST ${ }^{* 2}$ The University of Tokyo ${ }^{* 3}$ General Robotix Inc.

1.はじめに

基盤ソフトゥェアの再利用を促進し，次世代ロボットの開 発を効率化することを目的として， ロボットソフトウェアの 蓄積に適した分散コンポーネントフレームワークと, この 上に構築されたロボットワールドシミュレータを開発した。 分散コンポーネントフレームワークについては, 国際標準化 団体 OMG（Object Management Group）によって標準 規格として認められた RTC（Robotic Technology Component）を導入し，ロボットの制御ソフトウェアに RTC を適用可能とした．シミュレータについては，これまで主 としてヒューマノイドロボットの動力学シミュレーション を対象として開発してきた OpenHRP2 から，対象をマニ ピュレータ, 車輪型移動ロボット, 脚型ロボット等の一般 のロボットに拡大し，これに対応可能な動力学計算エンジ ンを新規に開発した。

我々は，新規に開発したシミュレータを OpenHRP3 (Open Architecture Human-Centered Robotics Platform 3) と名づけた. Humanoid から Human-Centered に変更になっていることに注意してほしい。本稿では, OpenHRP3 の概要について紹介する.

\section{2. 全 体 概 要}

OpenHRP2では，同じような処理を複数のコンポーネン トで重複して実装していたり，各コンポーネントのインタ フェース仕様のばらつきがあったりしていた. OpenHRP3 の全体構成の設計に当たっては, これらの問題点の解決を 図りつつ拡張性を実現するため, グラフィカルユーザイン タフェース (GUI), 動力学計算エンジン, モデルローダ, 干渉チェッカ, コントローラから構成される基本コンポー

原稿受付 2008 年 4 月 30 日

キーワード: Dynamics Simulator, OpenHRP, OpenRTM, RTC, Distributed Objects, Assembly-Disassembly Algorithm *1 ₹ 305-8568 つくば市梅園 1-1-1

$* 2$ 个 113-8656 文京区本郷 7-3-1

*3 个 305-0047 つくば市千現 2-1-6 A-30

*1 Tsukuba-shi, Ibaraki

${ }^{* 2}$ Bunkyo-ku, Tokyo

${ }^{* 3}$ Tsukuba-shi, Ibaraki

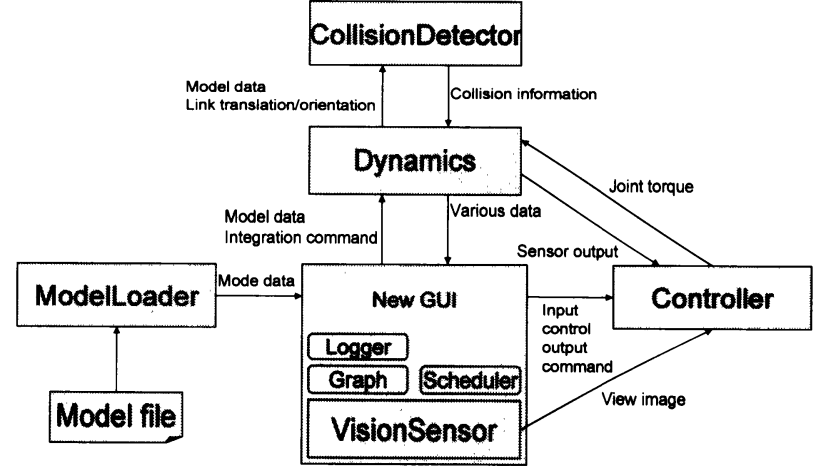

図 1 シミュレータ OpenHRP3 の構成

ネントに分割し，各コンポーネントの仕様を決定した。設 計したシミュレータの全体構成を図 1 に示す.

GUI を除く各コンポーネントは CORBA サーバとして 実装され，GUI はこれらを利用する CORBA クライアン トになっている. CORBA の実装としては, C++で実装さ れたサーバに対しては omniORB，Java で実装されている サーバと GUI は Java ORB を使用している。コントロー ラについては, RTC のインタフェースを備えた「コント ローラブリッジ」と置き換えることで， RTCによるコント ローラも利用可能としている，以下，各コンポーネントの 概要を説明する。

\section{3. コンポーネントの概要}

\section{1 モデルローダ}

シミュレーションの対象となるロボットや環境のモデル を記述するモデルファイルは, VRML97 フォーマットを用 い, Web3D の H-Anim WG で策定された関節やリンクの 表現方法に準拠した Prototypeノード拡張を利用している. VRML97 の後継規格であるX3D フォーマットの採用も検 討したが, モデル記述の要求に対して仕様が肥大化し過ぎ ていることから移行を見送った。

ロボットの機構は, 主に Prototype 定義された Jointノー ドと Segmentノードを用いて記述する. Jointノードは関 節を介した親リンクから子リンクへの接続を記述するもの である.Jointノードの定義の一部を図 2 に示す。 


\begin{tabular}{|c|c|c|c|}
\hline \multicolumn{4}{|l|}{ PROTO Joint [ } \\
\hline exposedField & SFString & jointType & “” \\
\hline exposedField & SFVec3f & jointAxis & 001 \\
\hline exposedField & SFVec3f & translation & 000 \\
\hline exposedField & SFRotation & rotation & 0010 \\
\hline${ }_{]}^{\text {exposedField }}$ & MFNode & children & [ ] \\
\hline
\end{tabular}

図 2 Joint ノードの Prototype 定義

\begin{tabular}{|c|c|}
\hline \multicolumn{2}{|l|}{ PROTO Segment [ } \\
\hline exposedField SFVec3f centerOfMass & 000 \\
\hline exposedField SFFloat mass & 0 \\
\hline exposedField MFFloat moments 0 f Inert & {$\left[\begin{array}{llllllllll}0 & 0 & 0 & 0 & 0 & 0 & 0 & 0 & 0\end{array}\right]$} \\
\hline exposedField MFNode children & [ ] \\
\hline
\end{tabular}

図 3 Segment ノードの Prototype 定義

\begin{tabular}{|llllll|}
\hline PROTO ForceSensor [ & & & & & \\
exposedField SFVec3f & maxForce & -1 & -1 & -1 \\
exposedField SFVec3f & maxTorque & -1 & -1 & -1 \\
exposedField SFVec3f & translation & 0 & 0 & 0 \\
exposedField SFRotation & rotation & 0 & 0 & 1 & 0
\end{tabular}

図 4 カセンサの Prototype 定義

ここに, jointType は関節の種類, jointAxis は関節軸, translation, rotationはそれぞれ親リンクからの相対位置 と姿勢, children は次に示す Segmentノードや子リンクの Jointノードを格納するフィールドである.

Sgmentノードはリンクを構成する剛体に対応する. 図 3 に Segmentノードの定義の一部を示す.

ここに, centerOfMassはリンクの重心位置, mass は 質量, momentsOfInertiaはリンク座標に関する慣性行列, children はリンクの形状やセンサ等の子ノードを格納する フィールドである。

センサとしては, 視覚センサ, 加速度センサ, ジャイロ, カセンサ等の情報を記述することができる. 例として, 力 センサの Prototype 定義を図 4 に示す.

ここに, maxForce, maxTorque はそれぞれセンサの定 格並進力とトルク, translation と rotationがそれぞれリン ク座標におけるセンサの位置と姿勢を示す。

モデルファイルは一般的に，キネマティクスや力学パラ メータを記述するトップレベルのファイルと, 各リンクの 形状モデルを記述する形状ファイルから構成される．トッ プレベルのファイルの中に，形状ファイル名が埋め込まれ ている. 現在のところ, トップレベルファイルは構造化エ ディ夕等で作ることを想定しているが，いくつか雛形を提 供しているので，これを修正することにより作成すること ができる，また，将来はグラフィカルな作成ツールも提供
する計画である。

各リンクの形状モデルは, $\mathrm{CAD}$ や $3 \mathrm{D}$ グラフィックス のオーサリングッール（例えば， $3 \mathrm{ds} \mathrm{Max}$ ）で作成し， VRML97 フォーマットで出力することにより, OpenHRP3 で利用可能となる。 また, 標準的な CAD のフォーマット から変換するフリーのツールが Web3D の repository で提 供されている．モデルファイルを読み込むモデルローダは， 現時点では vrml97.jar という Javaのライブラリを利用し ているが，C+十で実装したものに入れ替える計画である. VRML97 フォーマットを採用した利点としては，ロボット や環境の形状が, Web ブラウザ等の一般的なソフトウェア で確認可能となる点が挙げられる.

\section{2 グラフィカルユーザインタフェース}

グラフィカルユーザインタフェース（以下 GUI）の用途 として，シミュレータの実行に加えて，ロボット実機の制 御, ロボットの動作パターンの生成といった作業を想定し て仕様設計を行った。

ロボットに関連した上記の作業を GUI 上で実現するた めには，各作業に対応したデー夕構造と，デー夕構造を編 集・表示するための GUI 部品をまとめたものが必要となる. OpenHRP3 の GUI では前者を Item, 後者をView と呼ん でいる。これらを分離して構築することで，UI 機能の類似 項目を共通化することが容易となる。これによって，ソー スコード管理の労力を緩和し, 不具合の起きにくい GUI シ ステムを構築することができると考えられる。一方で，ロ ボットの研究用途に使用する際には，あらかじめ用意され た機能で十分であることはまれであり，ロボットに対する 何かしらの UI 機能を提供するプログラムをユーザ自身が 作成するケースが多く見られる。このような場合に，Item やView をユーザが追加できるような仕組みを提供するこ とができれば，ユーザによる UI 共通部分のコーディング 時間と，コード管理の時間を節約することができる.

これらのことを実現するために，Item やView を GUI を構成するための管理単位とし，それらをプラグインとし て導入できるという点を基本として実装を行った．設計し た GUI の構成を図 5 に，実行画面例を図 6 に示す.

PluginManager はプラグインの読み込みや実行を管理す る. 前述の想定作業では, 当然すべての Item と View を共 通化できるわけではないので，モードの切り替えによって 必要な ItemとViewのみを使用できるようになっている. 必要な Item と View はあらかじめ作業モードを設定してお き，ボタン操作によって切り替えを行う。モードの設定は XML で記述されたプロジェクトファイルに保存されており， 作業内容, 作業者の習熟度や要求によっては, プロジェクト ファイル自体を切り替えることで異なる使い方が可能とな る、各モードにおける Viewの表示は, View Configurator によって管理されており，好みの画面構成を保存しシフト 


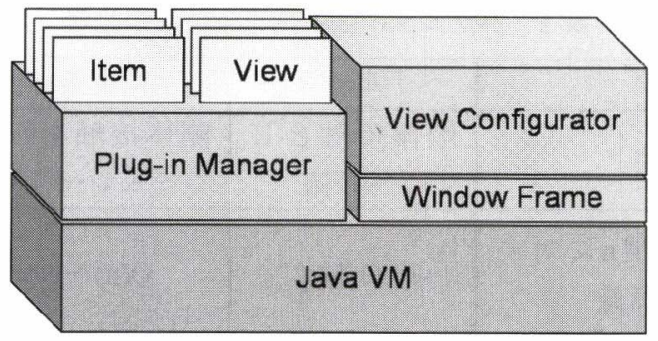

図 5 GUI の構成

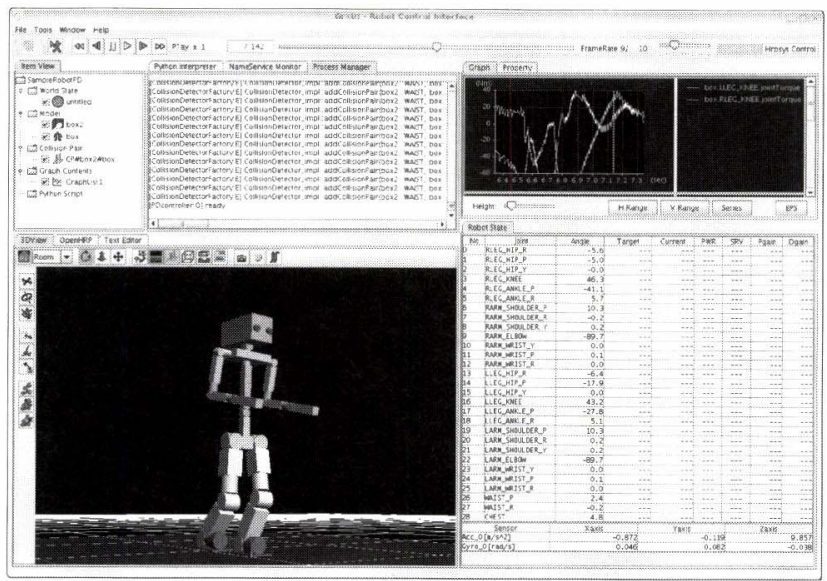

図 6 GUI 実行画面の例
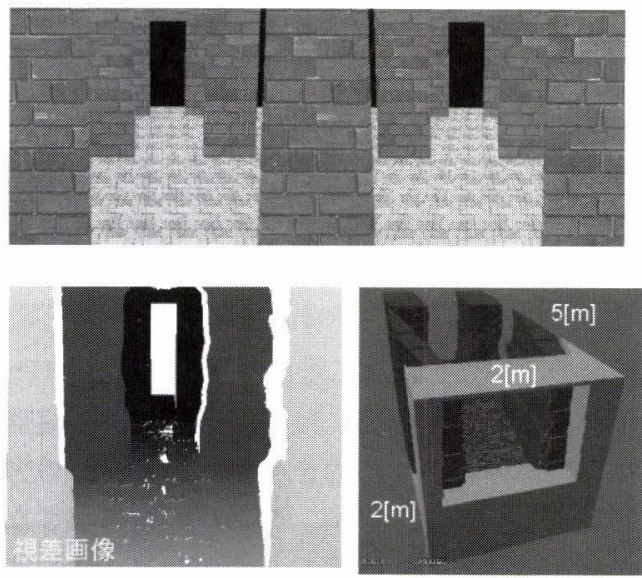

図 7 視野画像シミュレータの利用例

することができる。図 6 の例では，ロボットの三次元透視 罒, 力センサ等のセンサ值のグラフ, 各関節等の值が表示 されている。

OpenHRP3 では, 動力学シミュレーションだけではな くロボットの視野画像を生成し，己れに画像処理を適用す ることにより，ハンドアイシステム等のシミュレーション が行える。この視野画像生成機能も GUI の機能の一部と して実装されている。図 7 に適用例を示す。上段がステレ オカメラから見た視野画像, 下段左が視差画像, 下段右が 3Dグリッドマップである。

\section{3 干渉チェッカ}

干渉チェックについては, ソースコードでの配布を実現 するためフリーライセンスの OPCODE を拡張することに より実装した。OPCODEは，剛体の形状モデルを三角形 の集合で表現し，これをOBB (Oriented Bounding Box) と呼ばれるツリー構造にストアすることにより，剛体間の 干渉チェックを行うソフトウェアである。オリジナルの OPCODEでは, queryに対して干渉点の位置の集合のみを返 すが，ここでは各干渉点における法線べクトルと干渉深さ を返すように改造を行った。

干渉チェックのアルゴリズムとしては，凸集合間の最近点 を保持することにより干渉チェックを行うと同時に最短距 離を求める方法（例えば, 文献 [1]）もある。後述する拘束 条件法に基づく反力計算法で利用する場合，ある小さな值 よりも最短距離が小さくなった場合は衝突したとみなして 反力を発生させ，物体どうしがめりこまないようにしたほ うが動作が安定するのでこちらの方法が適しているが，一 方で任意の形状の非凸多面体を数值的に安定に凸集合に分 解することは難しいので, OpenHRP3 では OBB をデー 夕構造とするアルゴリズムを選択した。

\section{4 動力学計算エンジン}

本シミュレータの基幹となるのが動力学を計算するエンジ ンである. OpenHRP3では, FeatherstoneのABA（Articulated Body Algorithm) [2] [3] と，東京大学中村・山根 研究室で開発されたADA (Assembly-Disassembly Algorithm) [4] 二つの順動力学計算アルゴリズムを実装した。 $\mathrm{ABA}$ はロボットの自由度 $n$ に対して剛体リンク系の順動 力学を $O(n)$ で計算できるアルゴリズムである. ADAは, すべてのリンクが独立（関節による拘束がない）状態から スタートし，その関節で働く拘束力と発生する加速度を計 算しながら関節を一つずつ追加していく assembly ステッ プと, 最後に追加された関節からスタートし, assembly ス テップと逆の順序で全関節の最終的な拘束力と加速度を計 算する disassembly ステップから成る。閉リンク機構を含 む剛体リンク機構のシミュレーションが可能で, 計算量は 単一 CPUの場合 $O(n)$, 十分多くの CPUが利用できる場 合は $O(\log n)$ である [4].

ADA は, 数值的に安定であるという特徴を持つ. 古典 的な順動力学計算方法である単位ベクトル法と, 上記計算 方法を用いて計算したときの誤差を比較したグラフを図 8 に示す。このように，提案手法では誤差が $1 / 10 〜 1 / 100 に$ なっている，理由としては，単位ベクトル法では系全体の 慣性行列を考えるため, 逆行列の計算に誤差が生じやすい のに対し，開発した手法では扱う行列が大きくとも $6 \times 6$ までであり，大きな行列の逆行列を計算していないことが 考えられる。

上記の結果から, $\mathrm{ADA}$ を使うことにより従来の単位べ 
402

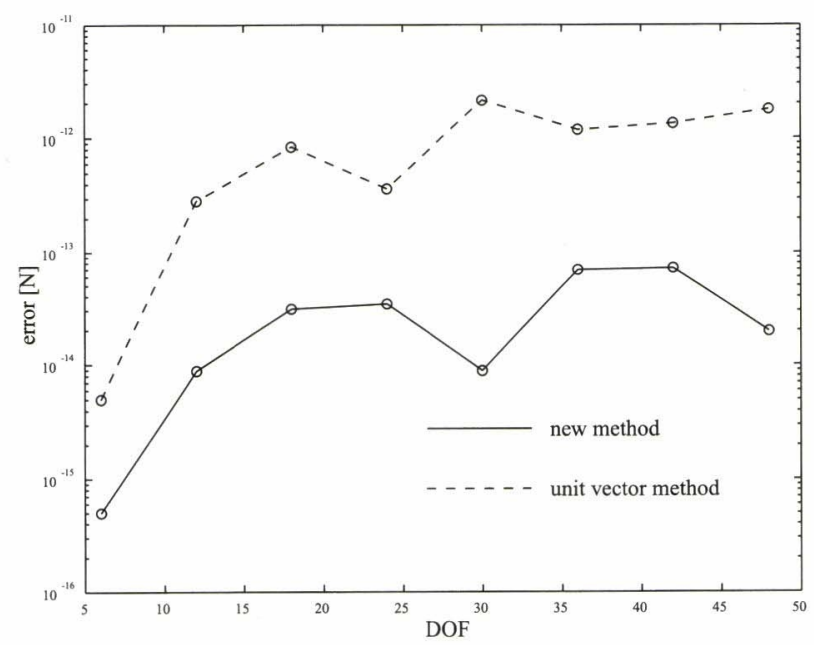

図 8 提案手法と単位ベクトル法による誤差の比較 (実線:ADA, 破線：単位ベクトル法)

クトル法より数值安定性が向上することが期待できる。し かし，質量分布に偏りがある場合や，質量に比べて力が大 きい場合には数值的に不安定になる可能性が高くなる。こ れについては, assembly ステップにおいて関節を追加する とき，その関節が結合しょうとする二つの部分的なリンク 機構の質量ができるだけ均等になるように追加順序を最適 化すること, 質量と比較して大きな力を受ける関節を追加 する順序をできるだけ遅くし，その部位のみ小さな時間幅 でシミュレーションを行うことにより対処可能であること が確認されている.

また，物体間に働く反力は，線形相補性問題 (LCP) を解 くことにより求める拘束条件法により計算しているが, $\mathrm{ABA}$ エンジンではこれを収束計算により解く方法 [3], ADA エ ンジンではピボット法により解く方法を採用した $[5]$.

ロボティクスの分野で使われている動力学シミュレータ では，反力をペナルティ法 (バネ・ダンパ法) で計算する 実装が多かった。 OpenHRP2 もぺナルテイ法を用いてい たが, マニピュレーション等の複雑な接触を伴う運動のシ ミュレーションをすることは困難であった。 ペナルティ法 と拘束条件法の簡単な比較を表 1 に示す。

一言でまとめると, ペナルテイ法は実装も簡単で計算も 高速であるが，正確なシミュレーションは困難で発見的に パラメー夕調整をする必要もあるのに対して, 拘束条件法 は実装も複雑で必要な計算量も多いが, シミュレーション は正確でアドホックなパラメー夕調整も不要である。コン ピュータグラフィックスやバーチャルリアリティ等の他分 野では拘束条件法が主として使われている.

ロボットの機構が弾性体を含む場合も, 機構モデルの中 にバネ・ダンパ要素を入れることでシミュレーションを行 うことが可能である. OpenHRP3 では ABA のエンジン がこれに対応している，例として，足裏部にゴムブッシュ
表 1 ペナルティ法と拘束条件法の比較

\begin{tabular}{|c|c|c|}
\hline & ペナルティ法 & 拘束条件法 \\
\hline 正確さ & $\begin{array}{l}\text { 剛体接触とし } \\
\text { ては不正確 }\end{array}$ & 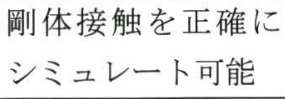 \\
\hline $\begin{array}{l}\text { 自由度nに対す } \\
\text { る計算量 }\end{array}$ & $\mathrm{O}(1)$ & $\mathrm{O}(\mathrm{n}) \sim \mathrm{O}\left(\mathrm{n}^{3}\right)$ \\
\hline $\begin{array}{l}\text { 接触点数mに対 } \\
\text { する計算量 }\end{array}$ & $\mathrm{O}(\mathrm{m})$ & $\mathrm{O}\left(\mathrm{m}^{2}\right)$ \\
\hline 積分の安定性 & 不安定 & 安定 \\
\hline パラメータ設定 & 必要で困難 & 不要 \\
\hline 実装 & シンプル & 複雑 \\
\hline
\end{tabular}

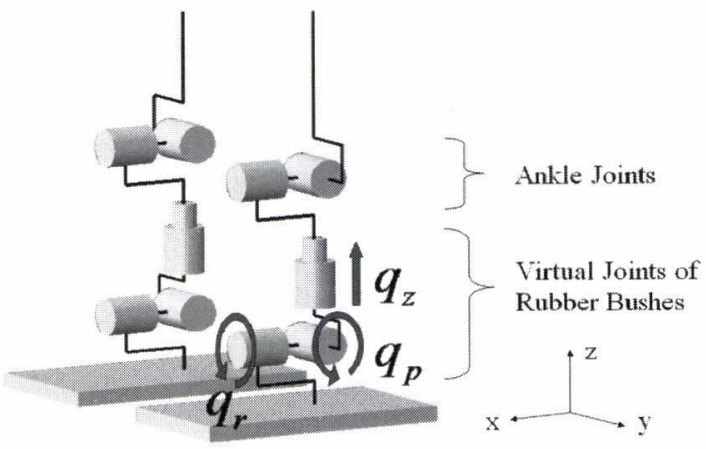

図 9 仮想バネ・ダンパ関節の例

を持つ脚式ロボットのシミュレーションを考える。このよ うな場合，足内部にゴムブッシュに相当する仮想的な関節 を組み込むことで，実機に近いシミュレーションを実現す ることができる，図 9 はゴムブッシュ機構に対応する仮想 関節のモデルである。

足首関節の下部に，新たに垂直並進・ピッチ・ロールの 3 軸を付加してあり，各関節には関節原点位置へ復帰しょう とする線形のバネ・ダンパ力を与えている。この方法の実 用的な問題点としては, バネ・ダンパの先に小さな質量の リンクが繋がることになるので, このリンクの動きが不安 定になることが挙げられる。この例の場合，ゴムブッシュ 機構の各軸に対して仮想的な減速器付サーボモータのロー 夕慣性モーメントを設定して順動力学計算を行うことによ り, シミュレーションの安定化を図っている.

拘束条件法は LCP を解くことに帰着するが，前述した 通り ABA エンジンではこれを収束計算により解く方法を 実装し，ADA エンジンではピボット法で解く方法を実装 している. 収束計算による手法は数值計算上安定な実装と することが容易であり，計算回数を制限することで，計算 速度と正確さのトレードオフを調整できるという利点も持 つ.ただし，収束計算を適用可能な行列の条件がピボット 法より厳しいため, 静止摩擦の組み込みには工夫が必要と 


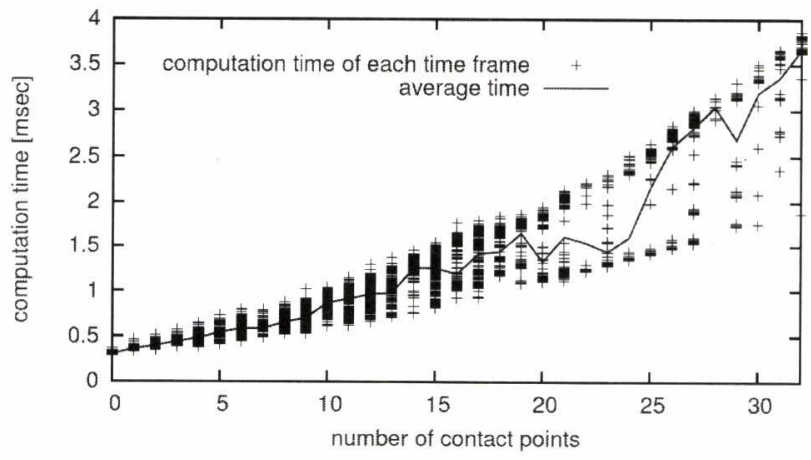

図 $10 \mathrm{ABA}$ エンジンを用いた計算時間の例

なる。一方, ピボット法では理論上有限の操作で完全な解 が得られ, 静止摩擦も摩擦円錐の多角錐近似により組み込 むことが可能である.ただし, 複雑な拘束条件に対して数 值計算上安定に解を得ることが難しい。

したがって，どちらの方法も実装は容易ではない，ABA エンジンでは, 接触点における力と加速度の関係を $\mathrm{ABA}$ に よって求める Kokkevisの手法と, Projected Gauss-Seidel 法を用いた LCP 解の計算等を組み合わせて, $O(n)$ の計算 量で安定に解を得る実装を実現した[3]，摩擦円錐を多角錐 により近似する必要がない点が特徴の一つである. ADA エ ンジンでは, 複雑な接触条件に対しても安定かつ効率的に 解を得ることが可能なピボット法のアルゴリズムを開発し た[5]. 結果として，どちらのエンジンを用いても，数十自 由度程度のロボットであれば，実用的な計算時間で安定な シミュレーションが可能であることを確認している。

図 10 はヒューマノイドロボット HRP-2 の動作シミュ レーションを $\mathrm{ABA}$ エンジンを用いて行った場合に, 1 回 の力学計算 (接触力・順動力学・積分の計算とし, 接触点 検出や描画，コントローラなどの処理時間は含まない）に かかる時間を，接触点の数に基づいて示したものである。

計測に用いたPCの CPU は Pentium D 940 （デュア ルコア，3.2[MHz]）である。これによると，仮想ゴムブッ シュ関節を含めて 36 自由度の HRP-2 に対して, 数十点程 度までであれば，力学計算自体は実時間に近い時間で計算 できている。したがって，ヒューマノイドの多くの動作に 対して十分高速なシミュレーションが可能であると言える。

ADA エンジンを用いて，接触を含む剛体リンク系シミュ レーションの例を図 11 に示す.

$\mathrm{ADA}$ は, 同等の能力を持つ既存手法と比べて高速な計 算が可能であることが分かっている [4] が，これをさらに 高速化するために複数 CPU による並列計算が可能なアル ゴリズム，およびそれを実行するソフトウェアを開発した。 また， 1 個以上の任意の数の $\mathrm{CPU}$ に対応して, CPU 数, 計算量, 数值安定性を考慮した最適なアルゴリズムを自動 的に生成する手法も開発した $[6]$.

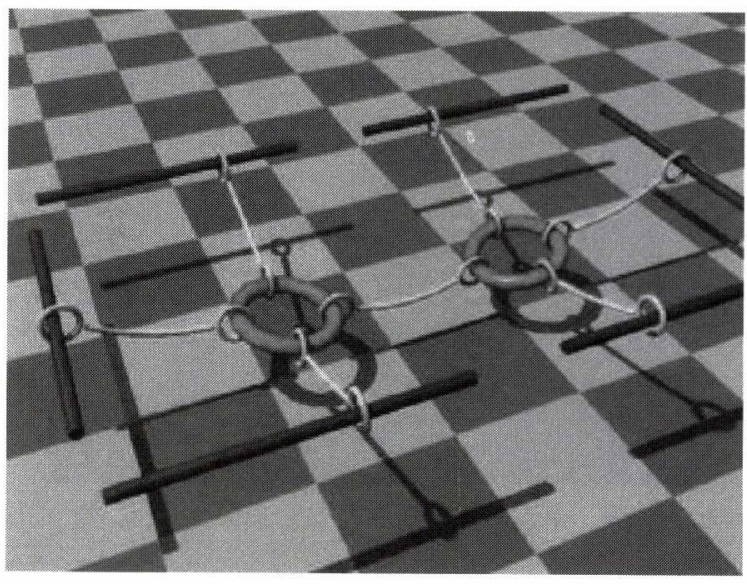

図 11 接触を含むシミュレーションの例

二つのエンジンの使い分けのガイドラインを次に示す.

・自由度数が 30 程度以下の場合, 機構にバネ・ダンパ要 素を含む場合は $\mathrm{ABA}$ エンジンを使う。

·自由度数が数十を超える場合, 球面関節が多く存在する 場合，大きな質量を持つリンクと小さな質量を持つリ ンクが混在する場合，並列計算機が使える場合は ADA エンジンを使う。

ただし，現時点では多様な場合における二つのエンジンの 十分な検証は完了していないので，両方を使ってみて比較 されることをお奨めする。

\section{5 コントローラ}

OpenHRP3 のユーザが作成するのは，基本的にはコン トローラである。例えば，視覚センサの值を処理し，その 結果に基づいてロボットの動作を決定し, これを動力学計 算エンジンに出力する. OpenHRP3 では, 前述した RTC の集合により，コントローラを実装する方法を採用してい る、詳細については, 本特集の別報 [7] を参照していただき たい.

\section{4. 応用例}

\section{1 マニピュレータ}

7 自由度マニピュレータ（三菱重工製 PA-10）を対象とし て，床面の対象物を把持して持ち上げるというシミュレー ションを行った例を示す（図 12 ).

マニピュレータは BASE および 7 個のリンクで構成し, BASEから順に各リンクを子リンクとして回転関節で接続 している (図 13). ハンドは平行 2 指とし, マニピュレー 夕先端のリンク (LINK7) の子リンクとして直動関節で接 続している。また，物体を把持するために，ハンドを構成 する各リンクと対象物との間の干渉チェックが行われるよ うに設定している.

コントローラとしては，各関節角度のレベルで PD 制御 を行うものを実装した。動力学計算エンジンとコントロー 
中 岡 慎一郎

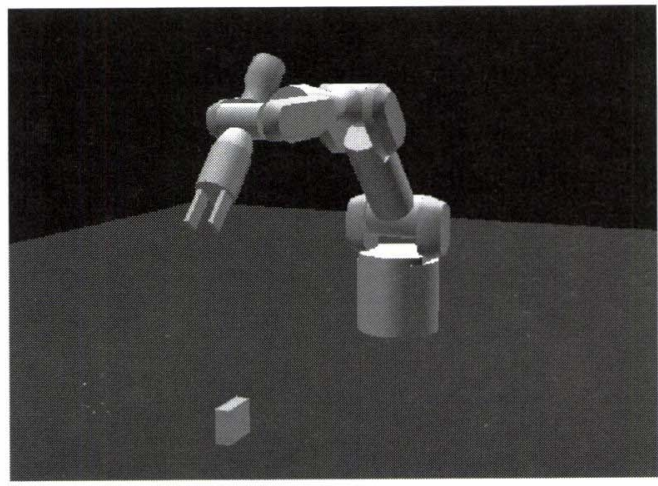

図 12 マニピュレータのシミュレーション例

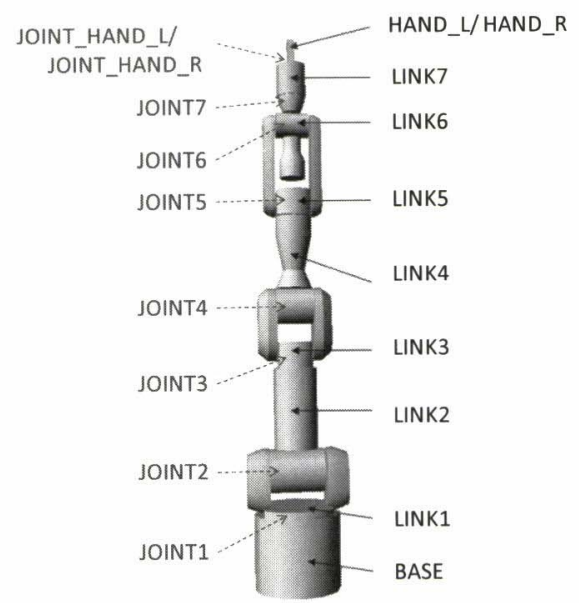

図 13 マニピュレータモデルの構成
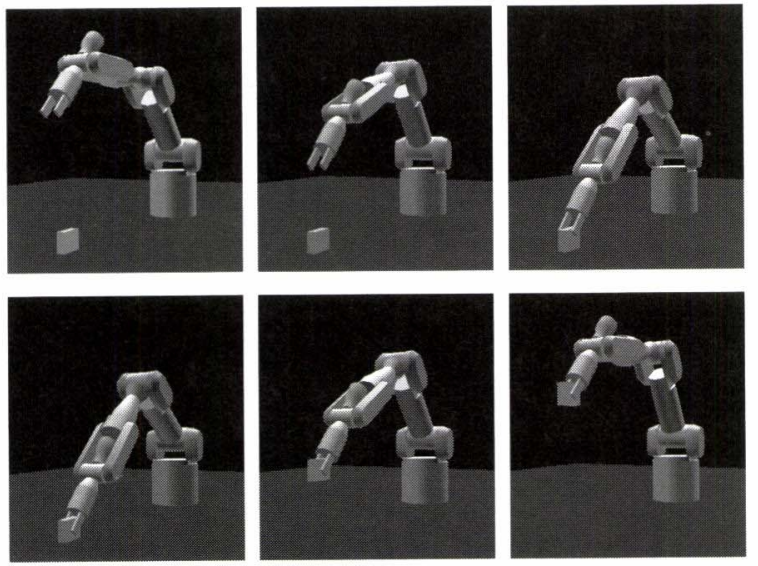

図 14 持ち上げ動作シミュレーションの結果

ラ RTC 間のインタフェース（コントローラブリッジ）を介 して, 動力学計算エンジンからは各関節の現在の角度や位 置を, コントローラからは各関節へのトルク入力をやり取 りする。図 14 に, 目標関節角度拈よび角速度を設定し, 対 象物の持ち上げ動作のシミュレーションを行った例を示す。

ここでは, 目標関節角度などを直接設定してシミュレー ションを行ったが, 逆運動学計算を行う RTC や目標位置
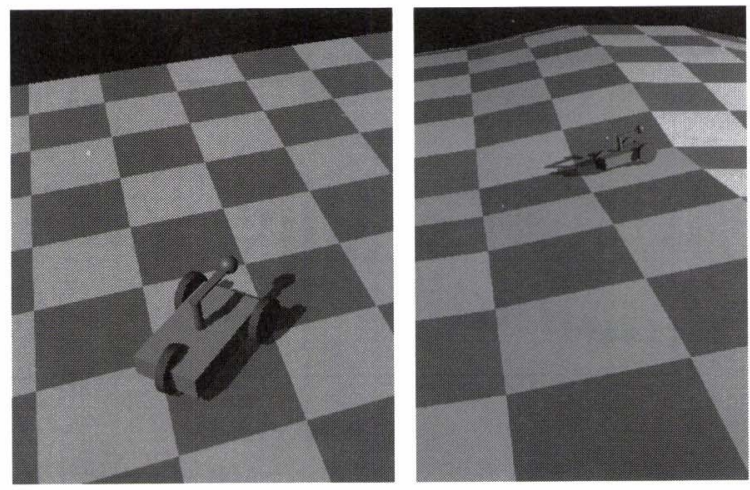

図 15 車輪型移動ロボットのシミュレーション例

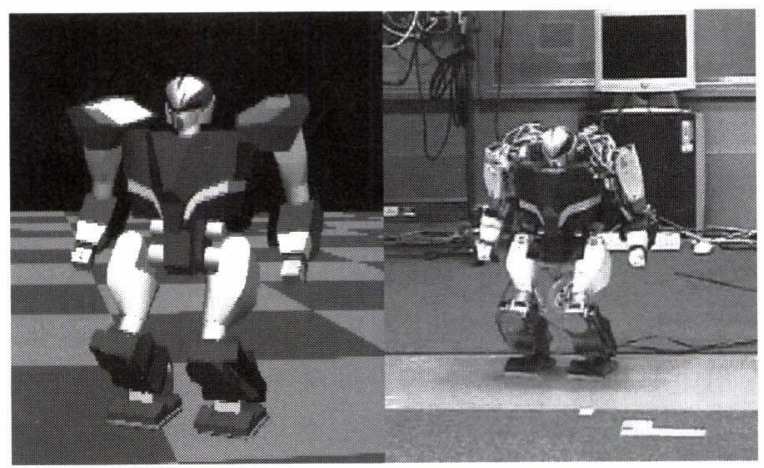

図 16 タップダンス運動のシミュレーション（左）と実験（右） の定性的比較

を入力するインタフェース RTC などの様々な RTC をつ なぎあわせることによって, 多様なシステムのシミュレー ションが可能である。

4.2 車輪型移動ロボット

車輪移動ロボットのシミュレーションの例を図 15 に示 す。車輪の形状は通常のリンクと同様にポリゴンモデルと して近似している，近似が粗い（ポリゴン数が少ない）場 合には実際の車輪と異なる挙動になることがあるため, 十 分細かいポリゴンモデルにする必要がある。剛体接触モデ ルに基づいているため車輪の変形を考慮することはできな いが，図 15 右のように任意の床面上での滑り，転倒を含む 運動をシミュレートできる。

4.3 ヒューマノイドロボット

小型ヒューマノイドロボットを対象として, シミュレー ション結果と実機実験の比較を行った例を示す（図 16 参 照).一般にヒューマノイドロボットのアクチュエータでは, PID 制御などによるサーボ系が駆動電流（トルク）を決め ているが, トルクを入力としてシミュレーションを行うに は関節の摩擦・粘弾性パラメータを正確に同定する必要が あり，多くのロボットでは現実的ではない。そこで，まず 理想的なサーボ系を仮定し, サーボ系への目標位置指令に 基づく簡易シミュレーションでどの程度実機と近い結果が 得られるかを検証した[8]. 小型ヒューマノイド実機を床反 


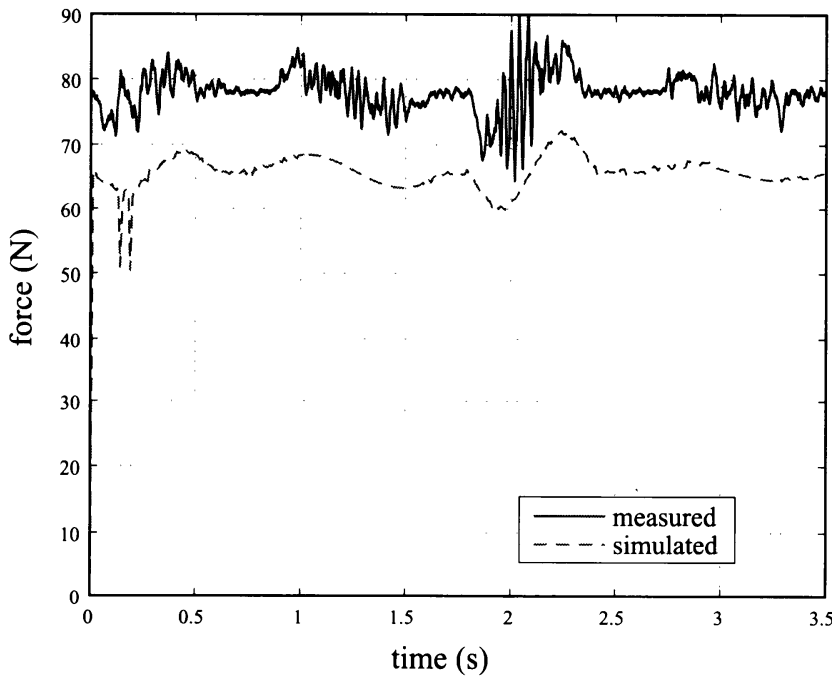

図 17 スクワット運動における床反力の実験結果（実線）とシ ミュレーション結果（破線）

力計上で動作させ，実験とシミュレーションにおける床反 力の鉛直方向成分を比較した例を図 17 に示す。シミュレー ションで用いた CAD モデルと実機の質量差によるオフセッ 卜を除けば，ほほ同じ挙動を示していることが分かる。ま たより複雑な衝突・接触を繰り返すタップダンス動作に おいても，定性的に同様の運動が現れることが分かった。

\section{5.おわりに}

OpenHRP3 の概要を紹介した. OpenHRP3 は, 2007 年 10 月より開発版の限定配布を行い，200 名以上がユー ザ登録して試用しているところである．2008 年度の早い時 期に，正式配布を開始する計画である。ライセンスについ ては検討中であるが，派生物（オリジナルのソースコード を直接改変したもの）についてはソースコードの無償開示 義務，再配布の権利の付与等のライセンス条項が伝播する， MPL（Mozilla Public License）系のオープンソースライ
センスで配布する方向で調整中である.

今後の展望としては, OpenRTM-aist とのさらに密な統 合, GUI の Eclipse 上への移植, 経路計画・動作計画ツー ルの開発等を検討中である. OpenHRP3 がロボットの研 究開発の共通基盤となることを期待したい。

謝 辞 本研究は, 文部科学省の科学技術振興調整費に よる「科学技術連携施策群の効果的・効率的な推進」の一環 として実施したものである。ここに感謝の意を表する。ま た，本研究の実施中に急逝された科学技術連携施策群次世 代ロボット主監谷江和雄氏に感謝するとともに, 謹んで哀 悼の意を表する。

\section{参 考 文 献}

[1] S.A. Ehmann and M.C. Lin: "Accurate and Fast Proximity Queries between Polyhedra Using Surface Decomposition," Computer Graphics Forum 2001, 2001.

[2] R. Featherstone: Robot Dynamics Algorithms. Kluwer Adademic Publishers, 1987.

[ 3 ] S. Nakaoka, S. Hattori, F. Kanehiro, S. Kajita and H. Hirukawa: "Constraint-based Dynamics Simulator for Humanoid Robots with Shock Absorbing Mechanisms," The 2007 IEEE/RSJ International Conference on Intelligent Robots and Systems (IROS 2007), pp.3641-3647, 2007.

[4] K. Yamane and Y. Nakamura: "Parallel $\mathrm{O}(\log N)$ Algorithm for Dynamics Simulation of Humanoid Robots," IEEE-RAS International Conference on Humanoid Robotics, pp.554-559, 2006.

[5] K. Yamane and Y. Nakamura: "A Numerically Robust LCP Solver for Simulating Articulated Rigid Bodies in Contact," Robotics: Science and Systems, 2008 (to appear)

[6] K. Yamane and Y. Nakamura: "Automatic Scheduling for Parallel Forward Dynamics Computation of Open Kinematic Chains," Robotics: Science and Systems, 2007.

[7] 安藤, 中岡, 神徳：“分散コンポーネント型ロボットシミュレータ. アーキテクチャーRT コンポーネントを用いた実機と可換な制御ソフト ウェア開発機能—”, 日本ロボット学会誌, vol.26, no.5, pp.407-410, 2008.

[8] K. Yamane and Y. Nakamura: "Dynamics Simulation of Humanoid Robots: Forward Dynamics, Contact, and Experiments," the $17^{\text {th }}$ CISM-IFToMM Symposium on Robot Design, Dynamics, and Control, 2008 (to appear). 


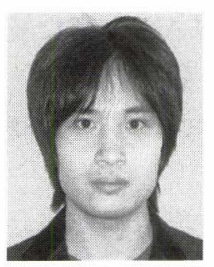

中岡慎一郎 (Shin'ichiro Nakaoka)

2001 年東京工業大学理学部情報科学科卒業. 2006 年東京大学大学院情報理工学系研究科コ ンピュータ科学専攻博士課程修了. 博士（情 報理工学)。2006 年 4 月より独立行政法人産 業技術総合研究所知能システム研究部門研究 員. 現在に至る。ヒューマノイドロボットに よる動き提示, 動力学シミュレータ, ロボットソフトウェアプ ラットフォームの研究に従事.

(日本ロボット学会正会員)

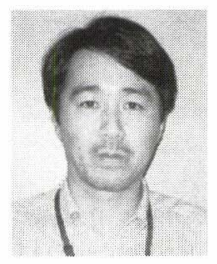

比留川博久 (Hirohisa Hirukawa)

1987 年 3 月神戸大学大学院自然科学研究科シ ステム科学専攻博士課程修了. 学術博士. 同年 4 月通商産業省工業技術院電子技術総合研究所 入所. 1994 年 3 月 1995 年 3 月米国スタン フォード大学計算機科学科客員研究員. 2001 年改組により独立行政法人産業技術総合研究 所知能システム研究部門ヒューマノイド研究グループ長, 2004 年 7 月知能システム研究部門副研究部門長, 現在に至る.ロボッ トの動作計画, ネットワークロボティクス, ヒューマノイドロ ボットの研究に従事. IEEE ICRA Best Video Award, ロボ ティクスシンポジア最優秀論文賞, 日本ロボット学会論文賞, 文 部科学大臣表彰科学技術賞 (研究部門) 等受賞.

(日本ロボット学会正会員)

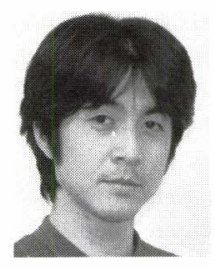

川角祐一郎 (Yuichiro Kawasumi)

2001 年九州大学大学院工学研究科航空宇宙 工学専攻修士課程修了. 同年川田工業入社. ヒューマノイドロボットのソフトウェア開発 を担当. 2003 年ゼネラルロボティックス株式 会社に出向後, シミュレータ, 制御ソフトウエ アの開発，製品サポートに従事。

（日本ロボット学会正会員）

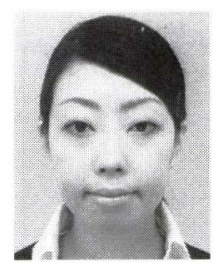

山野辺夏樹 (Natsuki Yamanobe)

2002 年京都大学工学部物理工学科卒業, 2007 年東京大学大学院工学系研究科精密機械工学 専攻博士課程修了. 博士 (工学). 2005 年 4 月より 2007 年 3 月まで日本学術振興会特別 研究員. 2007 年 3 月 (独) 産業技術総合研究 所知能システム研究部門研究員, 現在に至る. 組立動作計画，技能教示，教示動作の再利用に関する研究に従 事. 2008 年ファナック FA ロボット財団論文賞受賞. IEEE, 日 本機械学会, 精密工学会の会員. (日本ロボット学会正会員)

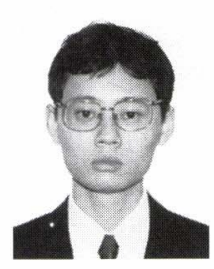

山根 克 (Katsu Yamane)

2002 年東京大学大学院工学系研究科博士課程 修了. 博士 (工学). カーネギーメロン大学研 究員を経て, 2003 年より東京大学大学院情報 理工学系研究科に勤務, 現在准教授. ロボッ ト・CGにおけるシミュレーション・運動生成・ 制御, ヒトの運動機能のモデリング・計測・解 析に関する研究に従事. 2004 年 IEEE Robotics and Automation Society の Early Academic Career Award, 2005 年度科 学技術分野の文部科学大臣表彰若手科学者賞などを受賞.

(日本ロボット学会正会員) 